谷地地すべり

と $\mathrm{HCO}_{3}$-の比率がやや高いが，全体では溶存物質の量 が最も少ない。大楖沼の減水率の大きさや，本地すへり 地の南側の流域は崩積土が非常にうすく流れ盤地形にな っていることなどから，滞留時間が短く降水と水質的に 類似した水であるとい党る。流出口をもたない大柳沼の 水が地下に浸透し，地严べり地北側の流域に湧出してい ることは明らかで，養漁場跡 (F-1) の水は溶存物質量 が増加するとともに，その組成も変化している。

本地すべり地内の地下水・湧水などの水質組成は，1 価の陽イオンに代って 2 価の $\mathrm{Ca}$ と，陰イオンでは $\mathrm{SO}_{4}$ が特徵的汇壃えている。地すべり地内の湧水はかつて13 個所で認められていたが，集排水工事の進捗に伴って逐 次消隇し，恒常的なものは SP-8に残っているにすぎな い。ここの水質は典型的な $\mathrm{CaSO}_{4}$ 型で, 調查時期による 変化はほとんどない。一方，集水井・トンネルなどの水 質は，当初は大柳沼などと同じ $\mathrm{Na}_{2} \mathrm{HCO}_{3}$ 型に近いもの であったところ，昭和 $50 \sim 51$ 年頃から $\mathrm{CaSO}_{4}$ 型に変化 してしまっている。この水質変化は地層中に介在する凝 扊岩の風化と関連するものと考壳られる。つまり当初带 水層を満していた浅層の地下水を排除していた施設が， 順次地すべり地内の深層の地下水を排出するようになっ てきたと解釈するのが自然であろう。

ボーリソグ孔の水質組成はこれまで述べたところとは 異なり，時期によって大きなバラッキがある。これは孔 内水の停滞時間と地下地質といら条件に起因するもの之 考党る。また，これまでの研究結果では，粘望性型の第 三紀層地すべり地に打ける地下水の流動にともなら水質 変化は一般に $\mathrm{Ca}^{2+}$ に比べて $\mathrm{Na}^{+}$が増加する傾向がみら れる。ところが, 谷地地すべり地では $\mathrm{Ca}^{2+}$ は大きく増

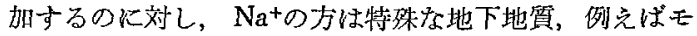
ソモリロナイトの多い粘土化した凝灰岩の場合を除くと ほとんど変化がないといえる。これは本地すべり地を構 成する岩石の物性に起图するものであるう。

\section{6. あとがき}

小論は, 谷地地すべり地の地下水の挙動について，地 すべり地を構成する地質条件，とくに岩石の物性とその 変形・破壊などによる空隚の性状に規制される地下水の 流動形態の特性について考察したるのである。本地すべ り地の地下水の流動型は通常の多孔質な帯水層中にみら れるものとは著しくその機構が異なる点を指摘した。な 打地下水流動にともなら水質変化の特徽についても言及 した。

\section{参 考 文 献}

1）岸本良次郎 (1975)：岩盤地すべり地内の地下水位の変動の 一例，地すべり，Vol. 13，No.1，8-15.

2) Ramsay, J.G. (1967): Folding and fructuring of rocks, 568p., McGraw-Hill, New York.

3) Thornthwait, C. W. (1948): An approach toward a rational classification of climate. Geographic review, No $38,55-94$.

4）寺川俊浩 西田彰一 近藤昌澉 (1979) : 谷地地すべりー上 くに岩盤地すべりと地質的背景一, 地すべり Vol. 16, No $16,9-18$.

5) Varnes, David J. (1978): Slope movement and types and processes, Landslides analysis and control, Transportation Research Boad, National Academy of Sciens. Washington, D.C., Special Report 176, 11-33.

（原稿受理日 昭和57年 4 月 5 日）

正嵒表

地すべり 第18巻第 3 号

地すべり発生機構に関する $2 \cdot 3$ の知見

一一伊良原地すべり地に叔汸観測例——

\begin{tabular}{|c|c|c|}
\hline ページ・行 & 愦 & 正 \\
\hline $\begin{array}{c}\text { p. } 42,7 \text { 行目 } \\
\prime \prime\end{array}$ & $\begin{array}{l}\text { 倉由由夫 } \\
\text { Fig. }\end{array}$ & $\begin{array}{l}\text { 倉田由夫 } \\
\text { Fig. } 1\end{array}$ \\
\hline p. 46, Table 1 (b) & $\begin{array}{ll}\text { No. } 4 & 9 / 11 \\
6.5 \mathrm{~m} & 4: 23\end{array}$ & $\begin{array}{ll}\text { No.4 } & 9 / 12 \\
6.5 \mathrm{~m} & 4: 23\end{array}$ \\
\hline " 右 15 行目 & 水晶発振る & 水晶発振子 \\
\hline p. 47 , 左 15 行目 & plak to plak & peak to peak \\
\hline p. 48, 存 7 行目 & Bull. D.P. R, I., & Bull. D. P.R. I., \\
\hline
\end{tabular}

